\title{
Imidazoline receptors in the heart: a novel target and a novel mechanism of action that involves atrial natriuretic peptides
}

S. Mukaddam-Daher and J. Gutkowska

\author{
Laboratory of Cardiovascular Biochemistry, Centre Hospitalier de L'Université de \\ Montréal Research Center, Campus Hotel-Dieu, and Department of Medicine, \\ University of Montreal, Montreal, Quebec, Canada
}

\begin{abstract}
Correspondence
S. Mukaddam-Daher

Laboratory of Cardiovascular

Biochemistry, CHUM-Research Center

Campus Hotel-Dieu (6-816)

3840 St-Urbain Street

Montreal, Quebec

Canada, H2W 1 T8

Fax: +514-412-7199

E-mail: suhayla.mukaddam-

daher@umontreal.ca

Presented at the $\mathrm{V}$ International Symposium on Vasoactive Peptides, Ouro Preto, MG, Brazil,

February 12-14, 2004

Research supported by grants (to S. Mukaddam-Daher and

J. Gutkowska) from the Canadian Institutes for Health Research (MO-15417) and the Heart and Stroke Foundation of Canada.
\end{abstract}

Received April 22, 2004 Accepted May 27, 2004

\begin{abstract}
Chronic stimulation of sympathetic nervous activity contributes to the development and maintenance of hypertension, leading to left ventricular hypertrophy $(\mathrm{LVH})$, arrhythmias and cardiac death. Moxonidine, an imidazoline antihypertensive compound that preferentially activates imidazoline receptors in brainstem rostroventrolateral medulla, suppresses sympathetic activation and reverses LVH. We have identified imidazoline receptors in the heart atria and ventricles, and shown that atrial $\mathrm{I}_{1}$-receptors are up-regulated in spontaneously hypertensive rats (SHR), and ventricular $\mathrm{I}_{1}$-receptors are up-regulated in hamster and human heart failure. Furthermore, cardiac $\mathrm{I}_{1}$-receptor binding decreased after chronic in vivo exposure to moxonidine. These studies implied that cardiac $\mathrm{I}_{1}$-receptors are involved in cardiovascular regulation. The presence of $I_{1}$-receptors in the heart, the primary site of production of natriuretic peptides, atrial natriuretic peptide (ANP) and brain natriuretic peptide (BNP), cardiac hormones implicated in blood pressure control and cardioprotection, led us to propose that ANP may be involved in the actions of moxonidine. In fact, acute $i v$ administration of moxonidine (50 to $150 \mu \mathrm{g} / \mathrm{rat}$ ) dose-dependently decreased blood pressure, stimulated diuresis and natriuresis and increased plasma ANP and its second messenger, cGMP. Chronic SHR treatment with moxonidine $\left(0,60\right.$ and $120 \mu \mathrm{g} \mathrm{kg}^{-1} \mathrm{~h}^{-1}$, sc for 4 weeks) dosedependently decreased blood pressure, resulted in reversal of LVH and decreased ventricular interleukin $1 \beta$ concentration after 4 weeks of treatment. These effects were associated with a further increase in already elevated ANP and BNP synthesis and release (after 1 week), and normalization by 4 weeks. In conclusion, cardiac imidazoline receptors and natriuretic peptides may be involved in the acute and chronic effects of moxonidine.
\end{abstract}

Key words

- Sympathetic nerve activity

- Imidazoline receptors

- Moxonidine

- Atrial natriuretic peptide

- Brain natriuretic peptide

- Hypertension

- Heart 


\section{Introduction}

The sympathetic nervous system (SNS) plays an important role in the regulation of blood pressure and cardiac function through the control of vasomotor tone, heart rate and the activity of the renin-angiotensin-aldosterone system. Sympathetic nervous activity is regulated in centers in the brain stem and transmitted to organs and blood vessels that are innervated by sympathetic nerve endings, modifying cardiac output, peripheral vascular resistance and renal function. Sympathetic overactivity is one of the mechanisms associated with several cardiovascular diseases, including development and maintenance of genetic hypertension. Clinical studies have shown that sympathetic innervation of cardiovascular organs is enhanced in young patients with essential hypertension, and that half of the enhanced total norepinephrine spillover - a measure of sympathetic activity, is derived from increases to the heart and kidneys (1). Hypertension-associated selective overactivity in the sympathetic nerves to the heart, kidneys and skeletal muscle vasculature, leads to development of left ventricular hypertrophy, predisposing to ventricular arrhythmias, increasing insulin resistance, and accelerating atherogenesis. Therefore, it is not surprising that most of the established cardiovascular therapy targets sympathetic nervous activity. Over the years, several types of antihypertensive drugs have been developed to inhibit SNS activity at multiple levels, including release, transmission or action. Peripheral $\alpha 1$-adrenergic and $\beta$-adrenergic receptor antagonists, postganglionic sympathetic neuron blockers and ganglioplegic agents, as well as central activation of $\alpha 2-$ adrenoceptors are routine ways to reduce high blood pressure by lowering peripheral SNS activity. The important clinical benefits of angiotensin converting enzyme inhibitors and angiotensin II receptor antagonists could perhaps be explained by their blunting or inhibiting the SNS effects in patients with cardiovascular disease. In contrast, some calcium antagonists which are successfully used to treat patients with hypertension and stable angina pectoris may have unfavorable effects in patients with impaired left ventricular function, due in part to baroreceptormediated activation of the SNS.

Therefore, it appears imperative that selection of vasoactive drugs for the treatment of cardiovascular diseases takes into consideration their effects on the SNS, where ideally treatment should also blunt sympathetic activity, or at least avoid activating it. Centrally acting drugs, such as clonidine and $\alpha$ methyldopa, reduce central sympathetic drive, and consequently maintain cardiac output, arterial tone and body fluid volume. Despite their clinical efficacy, the use of these "first generation centrally acting drugs" was often limited by their side effects, which include, dry mouth, sedation and mental depression. However, the discovery of imidazoline receptors and development of selective compounds, moxonidine and rilmenidine, which show an improved side-effect profile, revived interest in centrally acting drugs. Compared to the reference drug, clonidine, the "second generation centrally acting drugs", moxonidine and rilmenidine, show three to ten times higher affinity for imidazoline receptors than $\alpha 2$-adrenoceptors (2). It may be due to this selectivity that moxonidine and rilmenidine have fewer side effects, because imidazoline receptors have been shown to mediate hypotension, while sedation was attributed to $\alpha 2$-adrenoceptors.

\section{Discovery of imidazoline receptors}

Bousquet and colleagues (3) identified the primary site of the hypotensive action of clonidine as the nucleus reticularis lateralis region of the rostroventrolateral medulla (RVLM), which is a major source of sympathetic vasomotor drive via the preganglionic 
neurons in the spinal cord. These investigators noted that microinjections of clonidine, imidazoline and related compounds, in this area, decreased blood pressure, whereas phenylethylamine compounds did not. Also, imidazoline, but not non-imidazoline $\alpha 2-$ adrenoceptor antagonists, prevented imidazoline-induced hypotension when administered directly into this area. Accordingly, they proposed that the hypotensive action of clonidine and related imidazoline drugs is not mediated by $\alpha 2$-adrenoceptors, but may involve a new binding site that recognizes the imidazoline ring structure in these compounds (4).

Pharmacologic characterization by binding assays confirmed the existence of a population of imidazoline-specific binding sites that are insensitive to catecholamines in the brainstem RVLM of animals and man $(2,5,6)$. These studies clearly demonstrated that imidazoline binding sites are distinct from $\alpha 2$ adrenoceptors.

Binding studies have classified imidazoline binding sites into two main subtypes according to their affinity for clonidine (7). The imidazoline $\mathrm{I}_{1}$ sites, enriched in plasma membranes, have high affinity for $\left[{ }^{3} \mathrm{H}\right]$-clonidine and its analogues, whereas imidazoline $\mathrm{I}_{2}$ binding sites are sensitive to idazoxan and its analogues, but not to clonidine. Imidazoline $\mathrm{I}_{2}$ sites, which are exclusively mitochondrial, were shown to reside on monoamine oxidases (8). Further functional studies proposed the presence of non- $\mathrm{I}_{1} /$ non- $\mathrm{I}_{2}$ sites, located prejunctionally on postganglionic sympathetic nerve terminals, and $\mathrm{I}_{3}$ sites, which are implicated in insulin release from pancreatic $\beta$ cells. The focus of our research is on the $I_{1}$ subtype which has high affinity for clonidine, moxonidine and rilmenidine, and which has been implicated in cardiovascular regulation.

In a series of studies and a systematic review, Ernsberger (9) demonstrated that the imidazoline $\mathrm{I}_{1}$ binding sites fulfill the essential criteria for identification as functional receptors. The vasodepressor response to imidazoline is consistent with each of the four major criteria of specificity, function, location, and correlation of affinity with function. In addition, $\mathrm{I}_{1}$-receptors are subject to physiologic regulation, in a manner distinct from $\alpha 2$-adrenoceptors and, similar to other neurotransmitter receptors, imidazoline $\mathrm{I}_{1}$ binding can be downregulated by chronic exposure to agonists $(10,11)$. Imidazoline $\mathrm{I}_{1^{-}}$ receptors have at least one endogenous ligand, a "clonidine displacing substance" isolated from the brain and identified by Reis and coworkers (12) as agmatine (decarboxylated arginine), previously unknown in mammals. Agmatine has been shown to be widely distributed in many tissues, including the heart.

Two mechanisms of $\mathrm{I}_{1}$-receptor signal transduction have been identified. Ernsberger (9) demonstrated in PC12 rat pheochromocytoma cells, which lack $\alpha 2$-adrenoceptors, that $I_{1}$ receptor signaling includes activation of phosphatidylcholine-selective phospholipase $\mathrm{C}$ and generation of diglycerides and the release of arachidonic acid and its metabolites. The cascade involves activation of protein kinase $\mathrm{C}$ and mitogen-activated protein kinase (13). Other studies have also associated imidazoline $\mathrm{I}_{1}$-receptors to inhibition of adenylyl cyclase (14).

\section{Cardiac imidazoline $I_{1}$-receptors}

Imidazoline $\mathrm{I}_{1}$-receptors have been localized in the brainstem RVLM, and in the peripheral nervous system, including adrenomedullary chromaffin cells and carotid body, as well as in kidneys. In addition, we have demonstrated the presence of imidazoline $\mathrm{I}_{1}$-receptors in the heart. Using radiolabeled para-iodoclonidine ( ${ }^{125} \mathrm{I}-\mathrm{PIC}, 2200 \mathrm{Ci} /$ mmol; New England Nuclear, Boston, MA, USA), which binds to $\mathrm{I}_{1}$-imidazoline and $\alpha 2$-adrenoceptors, both receptor types were identified in the heart of multiple species, including rat, dog, and man. After irreversible blockade of $\alpha 2$-adrenoceptors, ${ }^{125}$ I-PIC 
Figure 1. Specific binding of radiolabeled para-iodoclonidine (125/-PIC) to human ventricular membranes. Data are reported as means \pm SEM $(N=3$ per group). Receptor maximum binding capacity (Bmax) and affinity $(\mathrm{Kd})$ were calculated by the Ligand computer program. ${ }^{*} P<0.003$ vs normal control (non-paired Student t-test). binding to heart frozen sections and atrial and ventricular membranes was competitively inhibited by increasing concentrations $\left(10^{-12}\right.$ to $\left.10^{-6} \mathrm{M}\right)$ of moxonidine, but not by epinephrine, implying specific imidazoline $\mathrm{I}_{1}$-receptor binding. Data from membrane binding and autoradiography were confirmed by immunohistochemistry and Western blotting (15).

Furthermore, we showed that heart $\mathrm{I}_{1^{-}}$ receptors but not $\alpha 2$-adrenoceptors are pathophysiologically regulated. Imidazoline $\mathrm{I}_{1^{-}}$ receptors were up-regulated in spontaneously hypertensive rat (SHR) atria. Compared to age-matched normotensive Wistar Kyoto rats, $\mathrm{I}_{1}$-receptor Bmax was 2-fold $(\mathrm{P}<0.01)$ higher in 12-week-old SHR right and left atria, but not altered in ventricles. Compared to corresponding normal controls, Bmax was 2-fold higher $(\mathrm{P}<0.01)$ in ventricles of hamsters with advanced cardiomyopathy and in hu-

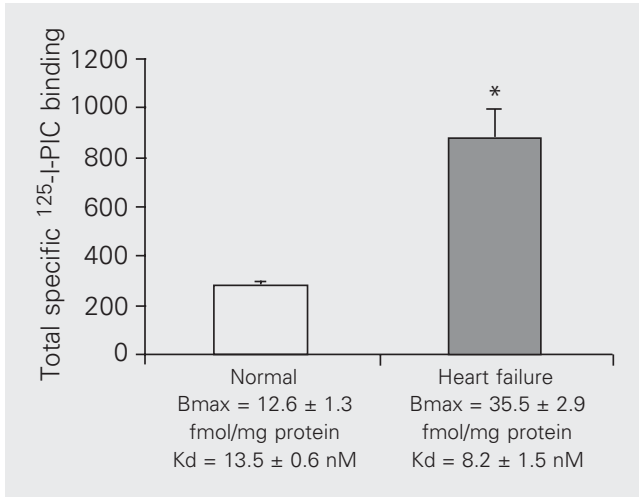

Figure 2. Bmax obtained from autoradiographic binding of radiolabeled para-iodoclonidine to frozen right atrial sections of normotensive Sprague-Dawley (SD) rats and spontaneously hypertensive rats (SHR), before and after 1 week of treatment with 3 doses of moxonidine, given SC, over 1 week. Data are reported as means \pm SEM $(\mathrm{N}=4-7$ rats per group). ${ }^{*} \mathrm{P}<0.01$ vs SD; ${ }^{*} \mathrm{P}$ $<0.01$ vs saline vehicle-treated SHR (non-paired Student $t$-test). man ventricles with heart failure (Figure 1) (15). We also demonstrated that cardiac $\mathrm{I}_{1}$ receptors, but not $\alpha 2$-adrenoceptors, are regulated by chronic in vivo exposure to the $\mathrm{I}_{1^{-}}$ receptor selective ligand, moxonidine. SHR (12-14 weeks old) received $0,10,60$, or 120 $\mu \mathrm{g} \mathrm{kg}^{-1} \mathrm{~h}^{-1}$ moxonidine (a generous gift from Solvay Pharmaceuticals, Hannover, Germany), via subcutaneously implanted Alzet minipumps (2ML1 and 2ML4; Cedarlane Laboratories Ltd., Hornby, ON, Canada), for 1 and 4 weeks. This treatment resulted in a dose-dependent decrease in specific ${ }^{125} \mathrm{I}$ PIC binding in atria by 1 week, with no further decrease after 4 weeks. Moxonidine $\left(120 \mu \mathrm{g} \mathrm{kg}^{-1} \mathrm{~h}^{-1}\right)$ decreased $(\mathrm{P}<0.01) \mathrm{I}_{1}$ receptor Bmax in right and left atria to normal levels (Figure 2), without altering $\alpha 2-$ adrenoceptor Bmax. These results showed for the first time that imidazoline $\mathrm{I}_{1}$-receptors and $\alpha 2$-adrenoceptors are present in heart atria and ventricles, and that only imidazoline $\mathrm{I}_{1}$-receptors are responsive to changes in the cardiovascular environment and to chronic exposure to the $\mathrm{I}_{1}$-selective agonist, moxonidine $(15,16)$. These results implicate heart imidazoline $\mathrm{I}_{1}$-receptors in cardiovascular regulation.

\section{Imidazoline and natriuretic peptides}

The efficacy of antihypertensive imidazoline compounds has been well established. Acute and long-term hemodynamic studies show that moxonidine reduces arterial pressure by lowering systemic vascular resistance while sparing heart rate, cardiac output and stroke volume. The effects are selectively mediated by activation of imidazoline $\mathrm{I}_{1}$-receptors and subsequent inhibition of sympathetic tone. Inhibition of renal sympathetic activity and/or direct activation of kidney imidazoline $\mathrm{I}_{1}$-receptors induce diuresis and natriuresis $(17,18)$, thus contributing to acute and long-term blood pressure control. In addition, the benefits of imidazoline compounds go beyond blood pressure control 
through their cardioprotective effects, antiproliferative and anti-arrhythmic, as well as their anti-inflammatory actions (19-25). Moxonidine and rilmenidine reduce left ventricular hypertrophy in patients and rats (20-22). Rilmenidine pretreatment ( $i v$ or $i c$ ) has been shown to dose-dependently prevent the occurrence of bicuculline-induced arrhythmias in anesthetized rabbits (23). Clonidine significantly decreases TNF- $\alpha$ production in macrophages and noradrenergic nerve terminals in in vivo lipopolysaccharide-treated mice (24). In type 2 diabetes, imidazoline compounds protect against proinflammatory interleukin 1ß-induced beta-cell apoptosis (25).

The beneficial effects of imidazoline may be centrally or peripherally mediated. However, identification of imidazoline $\mathrm{I}_{1}$-receptors and $\alpha 2$-adrenoceptors in the heart, mainly in cardiac atria, appeared very interesting. The atria are the primary site of atrial natriuretic peptide (ANP) production. ANP is a member of the natriuretic peptide family that also includes brain natriuretic peptide (BNP), C-type natriuretic peptide (CNP), and urodilatin, a family of peptides involved in blood pressure and volume regulation. The diuretic, natriuretic and vasodilator actions of natriuretic peptides are mediated by cell membrane natriuretic peptide receptor $\mathrm{A}$ (NPR-A) and NPR-B, through activation of guanylyl cyclase/cGMP, and NPR-C (clearance receptor), through inhibition of adenylyl cyclase/cAMP. The important role of ANP on chronic blood pressure regulation has been shown in a transgenic mouse model overexpressing ANP $(26,27)$, where elevated plasma ANP was associated with significant blood pressure reduction, whereas NPR-A knockout mice are hypertensive. The knockout studies revealed that the chronic hypotensive effect of ANP is mediated by attenuation of cardiovascular sympathetic tone (27). Independent of their role in blood pressure control, natriuretic peptides have antiinflammatory effects, and exert direct antihypertrophic and anti-fibrotic actions on the heart. Mice lacking NPR-A (which preferentially binds ANP and BNP) display a marked cardiac (atrial and ventricular) hypertrophy and extensive fibrosis and chamber dilatation by 3 months of age, as well as high mortality rate due to sudden death $(28,29)$. Mice with disrupted BNP develop multifocal fibrotic lesions in their ventricles (30). In addition, ANP has been shown to inhibit pro-inflammatory cytokine-induced nitric oxide production in human proximal tubular cells in culture (31).

Therefore, on the basis of the presence in the heart of both imidazoline receptors and natriuretic peptides, and on the functional resemblance between their actions, the following studies were performed to investigate whether activation of imidazoline $\mathrm{I}_{1}$ receptors by moxonidine may involve natriuretic peptides.

In acute studies, intravenous bolus injections of moxonidine (50 to $150 \mu \mathrm{g} / \mathrm{rat}$ ) in conscious normotensive rats (32) and SHR (33) reduced blood pressure and dose-dependently stimulated diuresis, natriuresis, kaliuresis and increased plasma ANP, and urinary cGMP, the index of ANP activity, suggesting that ANP is involved in the acute effects of moxonidine.

In chronic in vivo studies, SHR received moxonidine at 0,60 and $120 \mu \mathrm{g} \mathrm{kg}^{-1} \mathrm{~h}^{-1}$, over 4 weeks. Telemetric measurement of blood pressures revealed that the higher doses dosedependently decreased systolic, diastolic and mean arterial pressures and heart rate starting on the first day, reaching a minimum by 4 days, and maintained at low levels throughout the 4-week treatment. After 4 weeks, moxonidine at $120 \mu \mathrm{g}$ resulted in a significant reversal of left ventricular hypertrophy measured as the ratio of left ventricular weight to body weight (Figure 3). Also, in these hearts, moxonidine decreased elevated interleukin 13 levels (ELISA Kit, Biosource International Inc., Camarillo, CA, USA) in left ventricles from $166 \pm 4$ to $119 \pm 11 \mathrm{pg} /$ $\mathrm{mg}$ protein $(\mathrm{P}<0.01)$ (Figure 4$)$. Most im- 


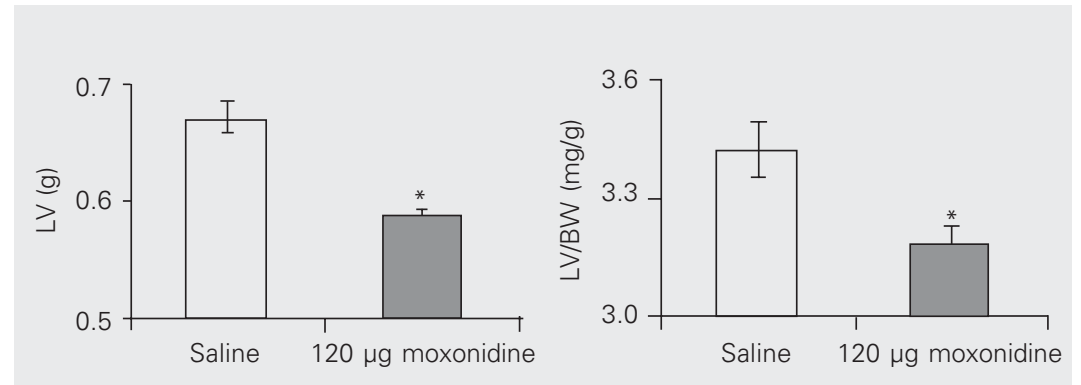

Figure 3. Left ventricular weight (LV) and left ventricular to body weight ratio (LV/BW) of saline vehicle-treated spontaneously hypertensive rats (SHR) and SHR after treatment with moxonidine $\left(120 \mu \mathrm{g} \mathrm{kg}^{-1} \mathrm{~h}^{-1}\right)$ for 4 weeks. Data are reported as means $\pm \mathrm{SEM}(\mathrm{N}=16$ rats per group). ${ }^{*} \mathrm{P}<0.01$ vs saline vehicle-treated SHR (non-paired Student $t$-test).

Figure 4. Interleukin $1 ß(I L-1 ß)$ measured in left ventricles of normotensive Sprague-Dawley (SD) rats, saline vehicle-treated spontaneously hypertensive rats (SHR), and SHR after treatment with moxonidine $\left(120 \mathrm{\mu g} \mathrm{kg}^{-1}\right.$ $\mathrm{h}^{-1}$ ) for 4 weeks. Data are reported as means \pm SEM $(N=5$ rats per group). ${ }^{*} P<0.01$ vs $\mathrm{SD} ;{ }^{*} \mathrm{P}<0.01$ vs saline vehicle-treated SHR (non-paired Student $t$-test).

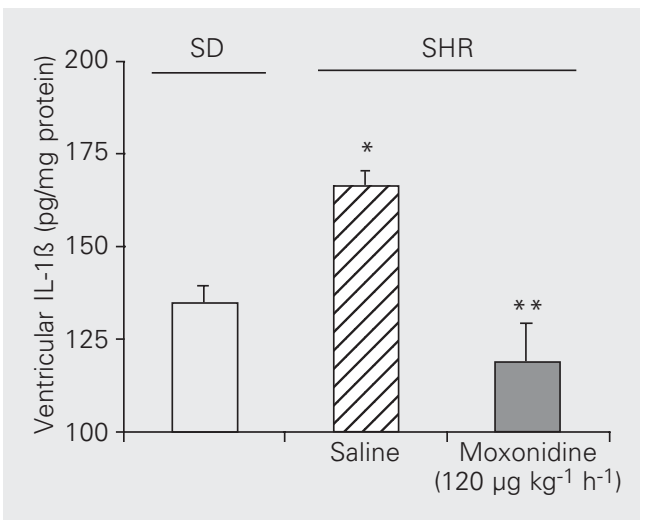

Figure 5. Plasma atrial natriuretic peptide (ANP) and B-type natriuretic peptide (BNP) in saline vehicle-treated spontaneously hypertensive rats (SHR), and SHR after treatment with moxonidine (120 $\mathrm{mg} \mathrm{kg}^{-1} \mathrm{~h}^{-1}$ ) over 1 and 4 weeks. Data are reported as means \pm SEM ( $\mathrm{N}=5-33$ rats per group). ${ }^{*} \mathrm{P}<0.01$ vs saline vehicle-treated SHR (non-paired Student $t$-test)

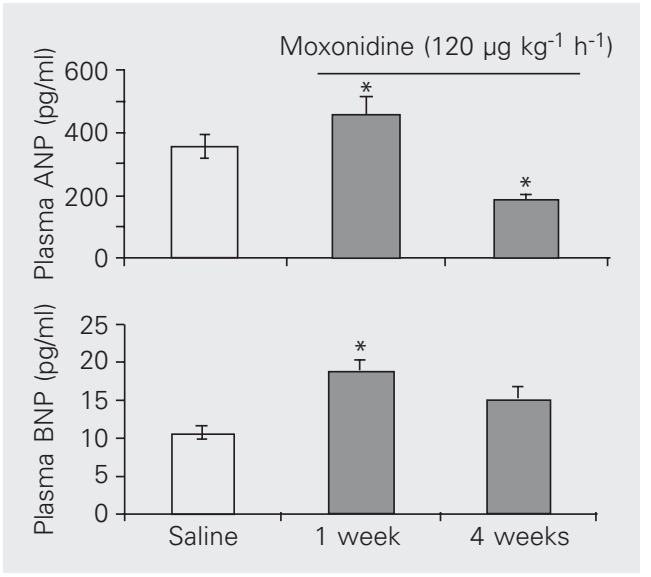

portantly, the effects were associated with increased atrial synthesis and release of natriuretic peptides, ANP and BNP (Figure 5), after 1 week, and normalization by 4 weeks of treatment $(34,35)$. Since natriuretic peptides and their receptors are present in the heart, we propose that moxonidine-stimulated ANP may act in a paracrine/autocrine manner to oppose the inflammatory and hypertrophic effect of overactive SNS and hypertension-associated cardiovascular environment.

We have not investigated the mechanism(s) of ANP production by moxonidine. The increase in ANP may be explained in part by moxonidine inhibition of sympathetic drive to the heart. Alternatively, imidazoline receptors and/or $\alpha 2$-adrenoceptors present in the heart may directly or indirectly affect ANP release from cardiac myocytes and/or ANP granules identified in the conduction system. Further studies are required to investigate the mechanism(s) of ANP release by moxonidine.

\section{Physiological significance}

It appears that the overall actions of the natriuretic peptide system are similar to, and most likely mediate, the effects of imidazoline receptor agonists. Increased natriuretic peptides may contribute to the therapeutic mechanism of imidazoline receptor agonists through their sympatholytic, anti-inflammatory, anti-fibrotic, and anti-proliferative effects. Accordingly, the use of drugs that potentiate endogenous natriuretic peptides, such as imidazoline receptor activators, should be favored. In addition, heart $\mathrm{I}_{1}$-receptors should be considered a target for antihypertensive treatment.

\section{References}

1. Esler M (2000). The sympathetic system and hypertension. American Journal of Hypertension, 13: 99S-105S.

2. Bricca G, Dontenwill M, Molines A, Feldman J, Belcourt A \& Bousquet $P$ (1989). The imidazoline preferring receptor: binding studies in bovine, rat and human brainstem. European Journal of
Pharmacology, 162: 1-9.

3. Bousquet P, Feldman J, Bloch R \& Schwartz J (1981). The nucleus reticularis lateralis: a region highly sensitive to clonidine. European Journal of Pharmacology, 69: 389-392.

4. Bousquet P, Feldman J \& Schwartz J (1984). Central cardiovascular 
effects of $\alpha$-adrenergic drugs: difference between catecholamines and imidazolines. Journal of Pharmacology and Experimental Therapeutics, 230: 232-236.

5. Meeley MP, Ernsberger PR, Granata AR \& Reis DJ (1986). An endogenous clonidine-displacing substance from bovine brain: receptor binding and hypotensive actions in the ventrolateral medulla. Life Sciences, 38: 1119-1126.

6. Haxiu MA, Dreshaj I, Schafer SG \& Ernsberger P (1994). Selective antihypertensive action of moxonidine is mediated by $\mathrm{I}_{1}$-imidazoline receptors in the rostral ventrolateral medulla. Journal of Cardiovascular Pharmacology, 24: S1-S8.

7. Michel MC \& Insel PA (1989). Are there multiple imidazoline binding sites? Trends in Pharmacological Sciences, 10: 342-344.

8. Raddatz R, Parini A \& Lanier SM (1997). Localization of the imidazoline binding domain on monoamine oxidase B. Molecular Pharmacology, 52: 549-553.

9. Ernsberger $P$ (1999). The $\left.\right|_{1}$-imidazoline receptor and its cellular signaling pathways. Annals of the New York Academy of Sciences, 881: 35-53.

10. Zhu H, Halaris A \& Piltez JE (1997). Chronic imipramine treatment dowregulates $I R_{1}$-imidazoline receptors in rat brainstem. Life Sciences, 61: 1973-1983.

11. Hamilton CA, Jardine E \& Reid JL (1993). Down-regulation of imidazoline sites in rabbit kidney. European Journal of Pharmacology, 243: 95-97.

12. Li G, Regunathan S, Barrow C, Eshraghi J, Cooper R \& Reis DJ (1994). Agmatine: an endogenous clonidine displacing substance in the brain. Science, 263: 966-969.

13. Edwards L, Fishman D, Horowitz P, Bourbon N, Kester M \& Ernsberger P (2001). The I1-imidazoline receptor in PC12 pheochromocytoma cells activates protein kinases $C$, extracellular signalregulated kinase (ERK) and c-jun $\mathrm{N}$-terminal kinase (JNK). Journal of Neurochemistry, 79: 931-940.

14. Greney H, Ronde P, Magnier C et al. (2000). Coupling of $I_{1}$-imidazoline receptors to the cAMP pathway: studies with a highly selective ligand, benazoline. Molecular Pharmacology, 57: 1142-1151.

15. El-Ayoubi R, Gutkowska J, Regunathan S \& Mukaddam-Daher S (2002). Imidazoline receptors in the heart: characterization, distribution, and regulation. Journal of Cardiovascular Pharmacology, 39: 875-883.

16. El-Ayoubi R, Menaouar A, Gutkowska J \& Mukaddam-Daher S (2004). Imidazoline receptors but not alpha2 adrenoceptors are regulated in SHR heart by chronic moxonidine treatment. Journal of Pharmacology and Experimental Therapeutics (in press).

17. Penner SB \& Smyth DD (1994). Central and renal $I_{1}$ imidazoline preferring receptors: two unique sites mediating natriuresis in the rat. Cardiovascular Drugs and Therapeutics, 8 (Suppl 1): 43-48.

18. Smyth DD, Pirnat D, Forzley B \& Penner SB (2003). Apparent absence of direct renal effect of imidazoline receptor agonists. Annals of the New York Academy of Sciences, 1009: 288-295.

19. Regunathan S, Feinstein DL \& Reis DJ (1999) Antiproliferative and anti-inflammatory actions of imidazoline agents. Are imidazoline receptors involved? Annals of the New York Academy of Sciences, 881: 410-419.

20. Mall G, Greber D, Gharenhbaghi H, Wiest G, Amann K \& Mattfeldt T (1991). Effects of nifedipine and moxonidine on cardiac structure in spontaneously hypertensive rats (SHR)-stereological studies on myocytes, capillaries, arteries, and cardiac interstitium. Basic Research in Cardiology, 86 (Suppl 3): 33-44.
21. Thomas L, Gasser B, Bousquet P \& Monassier L (2003). Hemodynamic and cardiac anti-hypertrophic actions of clonidine in Goldblatt one-kidney, one-clip rats. Journal of Cardiovascular Pharmacology, 41: 203-209.

22. Sadowski Z, Szwed H, Kuch-Wocial A et al. (1998). Regression of left ventricular hypertrophy in hypertensive patients after 1 year of treatment with rilmenidine: a double-blind, randomized, controlled (versus nifedipine) study. Journal of Hypertension, 16: S55-S62.

23. Roegel JC, Yannoulis N, De Jong W, Feldman J \& Bousquet $P$ (1998). Preventive effect of rilmenidine on the occurrence of neurogenic ventricular arrhythmias in rabbits. Journal of Hypertension, 16: S39-S43.

24. Szelenyi J, Kiss JP \& Vizi ES (2000). Differential involvement of sympathetic nervous system and immune system in the modulation of TNF-alpha production by alpha2- and beta-adrenoceptors in mice. Journal of Neuroimmunology, 103: 34-40.

25. Zaitsev SV, Appelskog IB, Kapelioukh IL, Yang SN, Kohler M, Efendic $S$ \& Berggren PO (2001). Imidazoline compounds protect against interleukin 1 beta-induced beta-cell apoptosis. Diabetes, 50: S70S76.

26. Steinhelper ME, Cochrane KL \& Field LJ (1990). Hypotension in transgenic mice expressing atrial natriuretic factor fusion genes. Hypertension, 16: 301-307.

27. Melo LG, Veress AT, Ackermann U, Steinhelper ME, Pang SC, Tse Y \& Sonnenberg $H$ (1999). Chronic regulation of arterial blood pressure in ANP transgenic and knockout mice: role of cardiovascular sympathetic tone. Cardiovascular Research, 43: 437-444.

28. Oliver PM, Fox JE, Kim R, Rockman HA, Kim HS, Reddick RL, Pandey KN, Milgram SL, Smithies O \& Maeda N (1997). Hypertension, cardiac hypertrophy, and sudden death in mice lacking natriuretic peptide receptor A. Proceedings of the National Academy of Sciences, USA, 94: 14730-14735.

29. Knowles JW, Esposito G, Mao L, Hagaman JR, Fox JE, Smithies O, Rockman HA \& Maeda N (2001). Pressure-independent enhancement of cardiac hypertrophy in natriuretic peptide receptor A-deficient mice. Journal of Clinical Investigation, 107: 975-984.

30. Tamura N, Ogawa Y, Chusho H et al. (2000). Cardiac fibrosis in mice lacking brain natriuretic peptide. Proceedings of the National Academy of Sciences, USA, 97: 4239-4244.

31. Chatterjee PK, Hawksworth GM \& McLay JS (1999). Cytokinestimulated nitric oxide production in the human renal proximal tubule and its modulation by natriuretic peptides: A novel immunomodulatory mechanism? Experimental Nephrology, 7: 438-448.

32. Mukaddam-Daher S \& Gutkowska J (2000). Atrial natriuretic peptide is involved in renal actions of moxonidine. Hypertension, 35: 12151220 .

33. Mukaddam-Daher S \& Gutkowska J (1999). The renal actions of moxonidine are mediated by atrial natriuretic peptide and involve the opioid receptors. Annals of the New York Academy of Sciences, 881: 385-387.

34. Menaour A, El-Ayoubi R, Jankowski M, Gutkowska J \& MukaddamDaher S (2002). Chronic imidazoline receptor activation in spontaneously hypertensive rats. American Journal of Hypertension, 15: 803-808.

35. El-Ayoubi R, Menaouar A, Gutkowska J \& Mukaddam-Daher S (2003). Normalization of up-regulated cardiac imidazoline $\left.\right|_{1}$-receptors and natriuretic peptides by chronic treatment with moxonidine in spontaneously hypertensive rats. Annals of the New York Academy of Sciences, 1009: 274-278. 